\title{
The Power of the Gift and the New Aid Modalities
}

\section{Rosalind Eyben}

\begin{abstract}
1 Introduction
This article looks at official international aid through the conceptual lenses of gift theory, with a case study of how the power of the gift shapes the meanings and social practices of aid, including the new aid modalities that involve budget support rather than projects. In so doing, I draw on Bourdieu's argument that social actors draw on the vocabulary of one set of rules and norms to explain a social practice that follows quite different principles, principles that they conceal even from themselves, while at the same time having practical (tacit or unexamined) knowledge as to how to follow these (Bourdieu 1990). My aim is to reveal to such practitioners that they are following the principles of the giving and receiving of gifts, albeit they couch their behaviour in terms of either exchanging contracts or delivering/demanding entitlements. I suggest they do this because this allows them to evade a conscious scrutiny of the operations of power in aid relationships. Further building on Bourdieu, I shall suggest that the aid relationship typifies his comment that:
\end{abstract}

In our societies, and at the very heart of the economic economy, we still find the logic of symbolic goods and the alchemy which transforms the truth of relations of domination, in paternalism. (Bourdieu 1998: 101)

Quite simply, my premise is that if donors and recipients were able to be more aware of what they are really doing in the practice of aid, including above all, recognising how power shapes the aid relationship, there might be more of a chance of the good intentions of aid, as manifested in campaigns such as 'Make Poverty History', making more of a real difference in the lives of those that international aid claims to help.

In two earlier pieces on power and relations in international aid, I have proposed that international aid can be variously understood as a contract, an entitlement or a gift. In explaining any specific case of giving and receiving aid, while I have suggested that all three concepts have explanatory utility, I have pointed out that those involved are likely to differ in their own explicit or tacit conceptual understandings of what aid is. These differences will be reflected in disagreement concerning the content and purpose of any aid relationship, including the normative (values and beliefs) and the procedural aspects of aid arrangements (Eyben 2005; Eyben with León 2005).

Today, official donors (governments and multilateral organisations) are increasingly designing instruments that make aid appear like an economic contractually binding agreement. This is because the new aid modalities are often mediated through an international financial institution (IFI) that thinks like a bank, while not always behaving like one. In many aiddependent countries, bilateral donors are moving from designing and managing standalone projects to associating with such IFls for providing budget support to recipient governments. Although the bilateral agencies concerned will be contributing grants, the whole arrangement is understood by the IFI, for example the World Bank, as a loan and the procedures associated with it are not entirely dissimilar from those associated with the loan we might get from the high street branch of our local bank for setting up a small business or buying a house.

On the other hand, many citizens and their governments in recipient countries - supported by those in donor agencies promoting rights-based approaches - prefer to see aid as an entitlement, to which they understand people in developing countries have a claim within the international human rights framework. Such an understanding has been resisted by donor countries during interminable debates over the Declaration of the Right to Development (Piron 2002). Then again, recent 
moves by the same donors towards mutual accountability and stronger recipient country ownership, as expressed in the recent Paris Declaration on Effective Aid (2005) could be interpreted as part of a shift in international aid to rights-based approaches, despite official resistance to the Right to Development (Eyben 2003). ${ }^{1}$

Thus for both official donors and recipients, aid is primarily conceptualised, with its associated rules and norms, as either an economic contract or an entitlement. Aid conceived as a gift has few friends in the official world of aid but it is attractive to anthropologists studying aid because it appears to illuminate what may be actually happening as distinct from what people say they are doing. So far, such studies have focused on the non-governmental sector, where ideas of philanthropy and charitable giving are much stronger than in official aid circles. Stirrat and Henkel (1997) look at how a gift of money from a private donor in the North moves through a chain of non-governmental organisation (NGO) relationships until it reaches its ultimate recipient. Drawing on the classic on gift theory by the French sociologist, Marcel Mauss, Stirrat and Henkel argue that while the money flows one way, symbolic reciprocity moves up the chain the other way. Most notably, they propose that while the gift is understood by the donor as an expression of social solidarity and the way it is given attempts to deny difference between the donor and the recipient, a gift in practice reinforces or even reinvents these differences (Stirrat and Henkel 1997). Sampson (2002) writes in a similar vein about the chain of giving and receiving, in which it is always the giver who has the power, stressing that there is no such thing as a free gift.

In an interesting article from an international relations perspective, Hattori takes this argument further and proposes that official government-togovernment aid is also a gift. Drawing on Bourdieu's ideas of symbolic domination, he suggests that in providing the gift of aid - which, because of equivalent lack of resources recipients cannot reciprocate - donors are able to reinforce their material and political dominance while disguising this as a generous gesture. Out of need, the recipients have no choice but to accept, and they therefore become complicit in the reproduction of the status quo that allows the donors to give aid in the first place (2001).
Hattori deploys gift theory to explore power relations within the global political economy. In contrast, I am interested in how aid relationships play out in a particular local context where those representing organisations with a global span struggle to connect with the cultural construction of power in the recipient country. I draw on my time as an aid practitioner in Bolivia to explore that question, including reflecting on my personal experience of power in the aid relationship, now querying how I could have behaved otherwise. From an early age, I had wanted to be an applied anthropologist, in order to do good in the world. I am still learning how power in all its disguises can feed on such ambition and convert good intentions to poor outcomes. ${ }^{2}$

The article is structured as follows. In the next section, I explore anthropological theories of the gift and their relevance for illuminating the operations of power in aid relations. This is followed by a reflexive account of my work in Bolivia with an illustration of how the power of the gift played out in the social practices relating to a programme of budgetary support. I conclude the article by suggesting that explicitly designing aid instruments as gifts might make aid more effective in promoting a social justice agenda than do the current aid modalities.

\section{Gifts, entitlements and contracts}

\subsection{What is a gift?}

There is no consensus as to what a gift is. If a gift is understood as a means of commodity exchange that was economic practice before the invention of money, its reciprocal character is emphasised. Thus, there is no such thing as a free gift. Every gift expects a return, even if the return is symbolic in character, or in the language of neoclassical economics, the giver chooses to optimise his preference for altruism. A gift understood in this way is not a gift but just a particular kind of exchange within the universal market in which all human interactions (transactions) take place. It can be distinguished from other forms of economic exchange by the lack of bargaining over equivalent value, the willingness of the giver to wait for some time before receiving a gift in return and by the absence of a formal legal contract.

While some sociologists and economists have applied rational choice theory to social exchange in which the focus is on the individual actor and where both giver and receiver seek to get as good they give 
(Carrier 1996), most anthropologists are more interested in the gift as an expression of a relationship. This is because it brings to the fore notions of power and morality that shape its character. This is overlooked in rational choice theory that is based on the metaphor of the impersonal level playing field of the market (Mirowski 2001). Thus, following the French tradition that originated with Durkheim and Mauss - and is currently exemplified in British anthropology by Strathern (1994) - I understand a gift as a material expression of a social relationship.

Post-modernism and feminism have favoured the return of the gift as a subject for academic consideration. Post-modernists appreciate its ambiguity and its potential to make positivist economists feel uncomfortable. They like its capacity to create an epistemic tremor, that is, to shake our convictions that we know how the world is structured (Callari 2002). Feminist studies have rescued the gift from its residual function as social glve - women's matters - in a world run according to the dictates of the market (Strathern 1994). The gift privileges relationships over transactions.

Mauss proposed that the ambiguity of the gift relationship is that it is at one and the same time interested and disinterested. A gift always has an intention behind it - and is therefore interested. On the other hand, if the intention is moral or sacred, then it is also disinterested. The giver sees himself as a vehicle or intermediary in the delivery of a gift from God. Thus, the giver should not be thanked because he has no interest in the gift. When gifts are seen as sacred it is bad manners to express gratitude to the human intermediary (Appadurai 1985). Along the same lines, when I was a representative of a donor agency, I disliked being thanked personally when authorising an aid expenditure. It implied there was a personal interest, whereas I wanted it to be understood that like Appadurai's religious devotee acting on behalf of God, I was simply acting on behalf of the taxpayer. It goes without saying that my actual motives and feelings were much more confused than such an outward expression of civil servant conformity would indicate. David Mosse, ${ }^{3}$ of the School of Oriental and African Studies, commented that when a donor representative visits a beneficiary community he is welcomed with ceremony and offered gifts but the economic benefit that the aid agency staff member gets out of the relationship - through his salary - is very much higher than any benefit an individual villager will get from the well or school building.

Gifts have a further ambiguity. As an expression of the sacred and/or the moral, a gift is a recognition of a social bond between giver and receiver, but that same recognition can be imbued with sentiments of power and even aggression. While both sides might want the relationship, of which the gift is the expression, in circumstances when one party - the donor - has more economic and symbolic resources than the other party, it is possible that the donor can pick and choose among his recipients, withdrawing his favours and transferring to another, without the abandoned recipient having any right of redress.

Furthermore, as mentioned earlier, the receiver with fewer resources than the donor may find himself in a position of accepting a gift which he cannot refuse (Callari 2002; Amariglio 2002). The power of the gift is that by accepting it, the recipient is not only taking the money but in so doing is acknowledging and reconfirming the relationship. This is the shadow side of the gift, commonly described as clientelism that very system that aid agencies are seeking to eradicate through their good governance agendas. As I shall now discuss, this dissonance between theory and practice explains why conceptualising aid as a gift has few friends in the world of donors and recipients.

\subsection{The gift has few friends in the world of aid}

The problem with the gift in a world of aid administered by bureaucracies is that it appears pre-modern, a patrimonial relic from a time when transactions were thought to be not efficiently impersonal but dependent on the quality of the relationship. For those committed to the development enterprise of spreading modernism and capitalism throughout the world gift exchange, as they understand it practised in primitive economies, was embedded in social relationships that constrained and limited the potential for individual enterprise.

The idea of the gift thus contradicts the idea of development, that is of a country or region progressing through various stages until reaching the 'developed' market economy maturity of the OECD countries. Because gift giving is understood by most economists as possessing a residual non-economic function in modern societies, when development 
practice, so exceptionally strongly imbued by economic thinking, looks to the observer very like a gift relationship, rather than a market transaction, a process of 'misrecognition' is required to make the gift look like something else. ${ }^{4}$

Some, such as very liberal economists, do recognise aid as a gift - charity - and object to it on those grounds, arguing that foreign direct investment has a much greater potential to develop the recipient country than could gifts received from a development bureaucracy. Those advocating aid, while generally sympathetic to the above argument, see aid as a short-term stop-gap that they argue is in any case, in the self-interest of the donor. It might look like a gift but it is really a market investment that brings a return through more people in the world having the wherewithal to buy the goods that the donor country produces. ${ }^{5}$

The alternative, more socially oriented position, objects to aid as a gift relationship because of the belief that developing countries are entitled to receive money from the richer countries. My own sympathies tend to lie in this direction. Our argument is usually couched in terms of the international human rights framework and global citizenship. The entitlement approach to aid seeks to construct a system of global governance that manages the global economy. Based on the thinking of T.H. Marshall about the national welfare state, social global citizenship would be achieved through policies of redistribution such as the Tobin tax. This alternative, rights-based view strongly dislikes the 'shadow' side of the gift because of its discretionary nature.

Both objections, from what we might call the right and the left ${ }^{6}$ of the aid debate (Therien 2002) owe their origin to Enlightenment liberal thinking concerning contracts, democracy, rights and individual autonomy. The Enlightenment looked back at its precapitalist past and saw thick, messy and unjust relationships in which privilege and patrimony decided life's chances. In that unpleasant past, value was not defined by what the market would pay but by the power of kings and priests. Wealth was not created through one's own effort but depended on a royal gift. People had no rights; they were subjects rather than citizens. Thus, development practice, as one of the most faithful adherents to the Enlightenment view of the world, is acutely discomforted with the idea that aid could be viewed as a gift. For international aid to resonate with its modernist purpose, it badly needs to relabelled as something else. This has long been the case with project aid but such aid appeared more discretionary than the current favoured arrangements of country ownership. The problem with projects from this perspective is that they were largely managed by donors so that while they appeared to be making a transfer of resources to the recipient, they were actually still keeping them. The paradoxical and elusive nature of the gift challenges the distinction between primary ownership and possession. It is possible to 'keep while giving' (Osteen 2002: 233, quoting Weiner).

\section{Today's vision, as expressed in the Paris Declaration} (see above) is one in which the recipient government, rather than the donor, decides on what to do with the aid which ideally should be given as budget support. These new aid modalities can thus, once and for all, abolish any suspicion that aid might be a gift and most satisfactorily work for both those who believe that aid is an entitlement, and those that see it as an economic contract. However, will these new modalities be capable of changing power relations or are they just disguising what continues to be a gift relationship? In the next section, I explore this question by drawing on direct experience from my time working in Bolivia as the head of the UK Department for International Development (DFID) country office from 2000-2. I do this by discussing how some bilateral donors, including DFID, moved from funding their own standalone projects to pioneering the new aid agenda of harmonisation, programmatic/sector aid and budget support through basket fund arrangements in which their grant aid was combined with credit from an IFI.

For readers not familiar with aid jargon, 'harmonisation' is the process by which donors agree to coordinate their aid policies and procedures in support of the recipient's objectives. 'Programmatic/sector aid' is the financing of a whole span of activities, for example the education sector, rather than a location-specific project. 'Budget support' is when the donor gives money to the recipient to manage rather than hanging on to the money and managing it through a donorcontrolled project. A 'basket fund' is when several donors put their money together into a single fund managed by the recipient against a pre-agreed plan without each donor's contribution being ear-marked for specific activities. 'Grant aid' is a gift! It is different from a loan that has to be repaid. 


\section{The power of the gift in Bolivia \\ 3.1 Personal reflections on power}

As already mentioned, one of the illuminating qualities of gift theory is that it is quintessentially concerned with relationships and the meanings, values and emotions that accompany these. It allows us to explore the impact we have upon each other and how this shapes possibilities for future action. It helps us understand aid practices as being much more than the instruments used or the agreements negotiated. At the same time, finding out the meanings those involved give to their actions is not easy, particularly as Bourdieu points out that through misrecognition, people may be ignorant of their own practice, dressing it up as something else. Power operates to encourage self deception (Chambers 1997).

In seeking to interpret their own understandings of their practice, I roughly categorise the sets of aid actors in Bolivia, as follows. As already mentioned, I suggest that staff in the IFls - in the case of Bolivia meaning the International Monetary Fund (IMF) and the World Bank - understand aid as an economic contract in which money is lent and returned with interest, at highly reduced rates for a low-income country as was Bolivia at that time. On first arriving in Bolivia, I found the IMF had a reputation for being both very influential with the country's President Banzer (a former military dictator) and entirely indifferent to poverty reduction, despite the IMF headquarters having committed itself to the new poverty reduction strategy process associated with debt relief.

What I refer to later as 'like-minded donors' were those with whom both my head office and myself as an individual were friendly, particularly the Netherlands and Sweden. Early champions of 'country ownership', meaning that recipients rather than donors should decide on what aid should be spent (provided it was on what donors wanted it to be spent on), we believed that aid was an entitlement. However, we discovered we did not always agree as to the extent to which it was the recipient government's entitlement or the entitlement of the citizens of the country. The recipient government, particularly the staff in the Ministry of Finance with whom we had the closest relationship, were also fervent enthusiasts for country ownership, meaning particularly the Ministry of Finance rather than other Ministries, let alone Parliament or citizens, should decide on how aid was spent. They would also have liked to see aid as an entitlement; in some cases their response to the perceived humiliation of having to ask for support was to act quite ferociously towards staff from donor agencies.

While most Bolivian academics, NGOs and representatives of civil society networks that I encountered and that DFID supported financially, felt equally humiliated by the country's aid dependence, they generally did not express it as openly as did some of their government compatriots, rather appearing to slip quite comfortably into clientelistic relations with donor staff. As I mention later, most citizens operating within a patronage system of social and political relations, incorporated donor staff into that wider system and openly and knowingly practised aid as a gift relationship.

My illustrative material for what follows is largely based on some publicly available reports and my memory, supported by some diary notes, records of meetings and odd snippets of emails to family and friends. I seek to write in reflexive mode, that is entailing critical reflection on my own actions, feelings and ways of knowing. I try to think myself back into how I understood what I was doing and believing in and how I felt when six years ago I emailed the following to my partner, in relation to the national consultation process relating to the development of Bolivia's donor-inspired Poverty Reduction Strategy (Eyben 2004):

Although I am sorry that you cannot come earlier it is just as well because in later July and early August will be the highlight of the National Dialogue which gets more and more interesting. This week I have been busy networking trying to get to grips with the fact that there is no donor coordination mechanism for talking about the poverty reduction strategy. I shall get fat on all the lunches but have got as far as the "like-minded" donors agreeing that we should formally propose such a mechanism.

And a few weeks later:

Meanwhile, the Bolivian Government/donor coordination group on the poverty reduction strategy, which was my idea, has now been formally established and has had its first meeting. And the World Bank has accepted DFID as a legitimate partner in the big ... programme for ... 
strengthening decentralisation. These are the two things I will be mainly working on in the next fortnight before you come... All in all, I feel very much that I am doing the kind of things I wanted to do and that there are lots of opportunities to make a difference.

'Making a difference' was how I phrased and believed it. I was also feeling good about myself and enjoying the power that came with making a difference. From these letters and notes, I find I was not sufficiently reflecting on the impact I was having on others, other than in triumphant mode. Thus for example, I was proud about making my first visit with two like-minded bilateral donor colleagues 'to beard the terrible IMF representative in his lair'.

... [he] was in fact rather nervous and went on the attack. When I remarked that we [the likeminded bilaterals] thought things were going too fast here for achieving a participatory process in formulating the $\mathrm{PRSP}^{8} \ldots$ said that IMF was not putting on the pressure but rather the UK Government [was] and he could show me a speech made last week by Gordon Brown to this effect. He said he had no objections to a donor/government working group on the PRSP but he didn't see any purpose on being part of this (our suggestion) because he knew nothing about poverty (bit unfortunate that he represents IMF in Bolivia!)

This pride in my own power as a mover and shaker is reflected in a subsequent independent evaluation of DFID's programme in Bolivia that observed that:

Since 2000, DFID has accorded high priority to improving donor coordination and harmonisation. DFID has been a very active player in the donor community, a key participant in governmentdonor working groups and has often taken a leadership role. It played a particularly important role in the 2000 dialogue and in influencing the donor community around the PRS.

(Flint et al. 2005: 34)

However, a footnote on the same page noted that one informant said that DFID had 'whipped the donors into a consensus'.

As part of the effort to make a difference, DFID moved out of its cramped space in the British Embassy into new offices where we had a very large meeting room with magnificent views over La Paz and the snow-capped Andean peak of Illimani. Here we were able to organise many coordination meetings with donors and consultations with civil society. The quality of the meeting room was far superior to that most donor and any Bolivian government offices could offer, let alone NGOs. Only very recently, when someone in IDS commented to me about how disempowered she had felt as a government official in visiting donors' offices in her own country, did I realise that our meeting room in La Paz might have had the same unfortunate effect. ${ }^{9}$ Whereas the room's purpose was to influence and impress other donor agencies, ${ }^{10} \mathrm{I}$ had largely failed to consider the unintended consequences of its symbolic impact on Bolivian government officials, let alone NGOs. One justification for the expense of the room had been to make it available free of charge to Bolivian civil society for their own autonomous meetings but during my time, this offer was only once accepted, interestingly by a newly formed campaigning association of people testing HIV positive.

I used the meeting room to rally those in the donor community with a shared interest and commitment to a rights-based approach to development, primarily challenging the perspective of the IFIs. In Bourdieu's terms, I was using symbolic capital to contest the IFI orthodoxy that perceived aid as an economic contract between freely choosing actors. In understanding aid as a right, I saw its potential as a catalyst for social transformation in Bolivia, encouraging citizens to make political demands on their government to spend the public budget (including the aid component) to respond to their interests, rather than just the interests of the small ruling elite. Yet, while I encouraged a different way of thinking about aid among those I met in Bolivia, at the same time I decided not to think too much as to whether aid by its very nature of being an unreciprocated gift could achieve such a transformation. As Shutt remarks in this IDS Bulletin, whether one's actions from a position of power to support empowerment are interpreted as helpful and creating power to or trying to gain control is highly subjective and is shaped by the beliefs and values of those one is seeking to help.

From the perspective of ordinary Bolivian citizens in a society where livelihoods and welfare significantly depended on securing a good patron, our new offices 
were seen as an opportunity for enhanced access to such a patron. One reason for moving out of the embassy had been to minimise security arrangements, so that Bolivian civil society representatives could visit the DFID office easily with no sense of harassment. What I had not anticipated were the regular unsolicited visits from rural community leaders requesting small gifts for local projects, such as a school building or a micro-dam. DFID's focus on using aid as an instrument to change policy meant that with some considerable embarrassment, we gave instructions to our receptionist to send these people away and across the street to the British Embassy, where there was a 'small gifts scheme' - but because of the forbidding nature of the building's security system they would never dare enter.

Observing the operations of power through the eyes of potential recipients requires an imaginative effort that perhaps most donor staff are rarely encouraged or able to take. Some two years after leaving DFID, I visited Peru. I went with two members from an IDS partner organisation to the offices of another bilateral agency in Lima, in search of funds for the continuation of their work. We deliberately did not introduce me as a former aid official. Empathising with the two Peruvians - with whom I had rehearsed this meeting, I felt very nervous. My heart beat fast and my mouth was dry. Carlos from the partner organisation started to explain the organisation's work and was interrupted by the official's secretary coming into the room with a message. She left and Carlos tried to continue. But the official, without even an apology, then called her back into the room and told her 'to let me know when he is free and I will go to him'. Once again, he did not apologise for the interruption and poor Carlos had to pick up what he was saying for a second time. Observing the official, who appeared a pleasant enough man, I realised he had no idea whatsoever of the impact he was making, nor of the significance of the meeting to the visitors.

How do these post-DFID reflections help me interpret the operation of the new aid modalities in Bolivia?

\subsection{The new aid modalities in Bolivia}

While I was working in Bolivia the country was becoming increasingly disturbed by waves of conflict between different sections of the population and the government (Crabtree 2005). Yet, at the beginning of the decade, the international aid system still saw Bolivia as one of its successes, piloting country-led approaches, basket funding, sector-wide approaches and coordinating aid in support of the Poverty Reduction Strategy. At the time, I was convinced of the progressive nature of such instruments. Putting money in the government's budget would strengthen the capacity of aid to become an entitlement; it would also contribute to dismantling the patronage system in Bolivia by refusing to give aid directly to the citizens through NGO projects but instead encouraging them to hold their state institutions accountable for the delivery of services to which they were entitled.

On this basis, I recommended that DFID, with some other bilaterals, co-finance through grant aid, a World Bank instrument - Programme Structural Adjustment Credit (PSAC) - that had been initially designed to refinance heavily indebted municipal authorities. We decided to join in because it seemed an excellent opportunity to influence the World Bank and the Government of Bolivia at the same time. The aim had been to work 'on both sides of the equation'." A parallel project supporting civil society strengthening to hold the government accountable for progress on decentralisation was designed by DFID but never implemented through lack of interest by other donors to support it, and the discouragement from the Ministry of Finance that saw 'donor driven' projects as an infringement of its entitlement to all aid from donor governments going to itself rather than to groups outside government (Eyben with León 2005).

For World Bank task managers, the PSAC's narrow purpose was to refinance local government so it did not collapse and the bilateral ideas concerning this aid instrument for promoting rights, gender equality, greater citizen participation and social inclusion, frankly seemed to baffle them. Within government circles, equally conflicting ideas were in evidence as to the purpose of the PSAC. For the Ministry of Finance facing a cash liquidity problem, the main concern was simply to get some money by any means, as I wrote in an email to my partner when DFID was also considering the possibility of providing some other budgetary support in addition to the PSAC:

... the most fun I have had this week is working on DFID providing emergency budgetary support to Bolivia ... I have been negotiating this through the Ministry of Finance. Doing it all in Spanish makes it even more of an amusing challenge. The 
background to this has been that Clare Short ${ }^{12}$ has said she wants to help Bolivia if they need it and I discovered that they have a $\$ 20$ million hole in their recurrent budget for this month and if they borrow or print money they go off-track.

Meanwhile, although the Ministry of Finance was seeking to negotiate the PSAC as quickly as possible, other parts of government could not agree as to the policy conditions required by the Bank, let alone those more ambitious objectives of the bilaterals. Heated discussions took place between different sections of the government concerning the powers of local government; the agony dragged out for several more months before the cabinet of ministers could agree to a policy statement on decentralisation that the Bank saw as a minimum precondition for releasing the loan

\section{During this time, I was writing to my partner that:}

... the decentralisation programme the Bank has been working on and to which we have provisionally committed $\$ 10$ million in co-financing is now being pushed through the final appraisal and negotiation stages at breakneck speed (just because no new IDA [International Development Association] money has been disbursed this year which is one of the reasons for Bolivia being short of money) and the wrap up is in Washington in the week of 18th December. This trip I can't wriggle out of - highly inconvenient but I am trying to get flights from here to Washington and then directly to London to arrive on the morning of the $22 n d$ as previously planned.

An evaluation of PSAC (Helmsing et al. 2003) points out that although the 'social' issues which were the bilaterals' concern were eventually included in the loan, there was no provision for ensuring these concerns were addressed at implementation. It was certainly not this particular aid instrument that contributed to the strengthened voice of the indigenous majority but organised political movements that challenged the ruling elite and eventually came to power through the elections at the end of 2005.

Some commentators saw our 'disproportionate' insistence on 'social', as distinct from financial issues as a sign of over-interference. 'Ounership' is fine in seminars, but in practice...' (ibid.: 49) On the other hand, the evaluation notes that of the total funds provided only 50 per cent went to the government agencies and authorities designated to receive them in accordance with the PSAC terms and conditions (ibid.: 14). The rest of the money disappeared into the general coffers of the state and the evaluation of DFID concludes that this was not a successful initiative. The PSAC was an instrument that ignored the World Bank's own findings that Bolivia's political system was patrimonial and clientelist, judging this as the principal cause of poor public sector performance and lack of responsiveness to poor people's needs and demands (World Bank 2000). PSAC was an example of what two other World Bank analysts have described as 'skipping straight to Weber', meaning that donors pretend to themselves that with some technical assistance and the financial incentives offered by aid, state institutions in a country such as Bolivia can be rapidly converted into an ideal impartial and incorruptible bureaucracy (Pritchett and Woolcock 2004).

From the perspective of the World Bank country representative, PSAC was part of a political agenda which would allow his agency to be the lead donor harmonising the efforts of the rest of the aid community. It was his aim to make this the forerunner of a Poverty Reduction Strategy Credit (PRSC) where his head office would expect its country representative to play a strong role in lining up all the donors behind its leadership.

PSAC was an instrument that gave me personal satisfaction. It supported my ideal of what statecitizen relations should be; it involved managing large sums of money and having one-to-one negotiations with the Minister of Finance; it provided the opportunity to be in there with the big boys with high-powered missions to Washington where, watched by my like-minded colleagues on a video link that connected La Paz with the World Bank headquarters, I convinced the regional vice-president that the social issues had to be included.

On the other hand, in terms of aid effectiveness, the evaluation of DFID's programme cited earlier concluded it was the support given to civil society through our small strategic impact fund that proved to be the most effective aid in terms of impact, for example to a network of organisations, known as the Comité Enlacé where DFID's support 'was described as open, process-orientated, non-imposed, 
empowering and participatory' (Flint et al. 2005: 20). Yet, such support was clearly seen as a gift by both donor and recipient - one in which I as the donor representative had considerable influence, for example when I informed the network that DFID would withdraw financial support should its leader stand as a political party candidate in the 2002 elections. I and my colleagues were also influential in our choice of whom to support in civil society. It was discretionary and it meant that some groups had more access to money than others. ${ }^{13}$ Although informed by political analysis and good intentions, it was patronage nevertheless. We never ran any kind of challenge fund programme to which all civil society organisations could apply. In the one instance I did consider doing so, Bolivian colleagues advised me against it, arguing (I believe correctly) that such a competitive fund could risk breaking up delicately balanced coalitions

That aid is discretionary, not subject to legally binding contracts, became apparent to DFID and the Bolivian Government in late 2003. Following the invasion of Iraq and the resulting budgetary demands on the aid programme, London decided in November 2003 to cut back sharply and rapidly on its financing of other middle-income countries, including Bolivia, so as to still meet its commitment to raising the percentage of bilateral spending on low-income countries to 90 per cent by 2005/6. With some other donors, DFID had been involved in several basket fund arrangements in addition to PSAC. One was support to a national agricultural research programme, known as SIBTA. As the DFID representative, and at the suggestion of the Dutch, along with the other bilateral donors I signed a contract with the government in accordance with international civil contract conventions established at The Hague. When DFID at the end of 2003 took the unilateral decision to cut its support by f2.1 million, one of the other donor representatives suggested to the Bolivians that they take the case to The Hague and sue DFID for breach of contract. My informant concluded that the government decided not to do so because of the damage it would cause to relations between the two governments. ${ }^{14}$ The independent evaluation concludes however, that these cuts were damaging to DFID's reputation:

The fact that DFID raised so many expectations and built so many close working relationships has made its sudden decision to reduce its bilateral programme even more of a disappointment. This experience is bound to make some partners more sceptical of DFID's long-term commitment to Bolivia, the region and the particular issues that it has championed so effectively since 2000 .

(Flint et al. 2005: 17)

Thus, although through adopting the new aid modalities, DFID appeared to be switching away from practising aid as a gift, ultimately its behaviour revealed that this was not the case. It was seen as a badly behaving, capricious giver - revealing the shadow side of the gift relationship - and undermining the relations of solidarity and potential long-term support that is the positive aspect of the gift. To be effective, contracts and entitlements need the force of law. Gifts, on the other hand, require shared values and a moral commitment to the relationship, something that DFID did not recognise in its enthusiasm for the contractual forms that accompanied the new ways of doing aid.

As a final note, even the Bank broke its own contractual procedures by subsequently paying out a further instalment of the PSAC despite policy benchmarks largely not having been met. I was told that it did this under pressure from the US Government, worried that Bolivia's deepening financial crisis would lead to political disturbances, which would have a ripple effect throughout the region and damage US interests. ${ }^{15}$

\section{Conclusion}

In this article, I have tried to identify some of the reasons why the new aid modalities are attractive to both donors and recipients. I have suggested that for both parties these modalities represent modernity and thus at first sight reduce the dissonance between the kinds of aid instrument and its goals. Budget support merges a bilateral donor's grant with an IFI's loan - thus conceptualising it as an impersonal market transaction. For recipient governments, such as in Bolivia, the emphasis on country-led approaches provides the opportunity to see aid as an entitlement with a growing emphasis on two-way accountability rather than simply one way back to donors.

In addition to this apparent resolution of dissonance between instruments and the favoured theory of aid as either contract or entitlement, for donors there is the attractiveness of policy-based lending/grants involving much larger sums of money than traditional projects and therefore (in a simplistic input-output 
logic) likely to deliver bigger results. From a more personal perspective, while some staff in bilateral agencies might feel their individual contribution to a basket fund initiative might not be noticed (Nickson 2002), my own experience was that the policy dialogue associated with the new aid modalities gave me a seductive buzz (a sensation of power) that working on the tedious implementation details of little bilateral projects quite often failed to do. From conversations with a number of DFID social development advisers, I have the impression that this is not an uncommon sensation.

Yet, for the time being at least, there is not a great deal of evidence in the ignored reality of everyday practice that aid has stopped being a gift, whatever claims might be made to the contrary. The recent accusations by African governments concerning the failure of donors to meet their commitments made in 2005 at Gleneagles are an illustration of aid's continued discretionary nature. If aid as a gift were to be 'outed', how would that change the nature of power in the relationship? Navarro argues in this IDS Bulletin that the uncovering of the misrecognition constructed by power provides the opportunity for emancipation. At the very least, it would offer the possibility of putting aid relationships on a more honest and critically reflective footing. It would

\section{Notes}

* I am most grateful to Katy Gardner, as well as to Colette Harris and Cathy Shutt for their helpful comments on an earlier version of this article.

1 The emphasis on mutual accountability in the Paris Declaration on Aid Effectiveness is however more geared towards a contractual understanding of aid where the primary aim is efficiency (OECD 2005).

2 See Ch. 9 in Crewe and Harrison (1998).

3 In a presentation at a conference on 'Development People' held at Queen Elisabeth House, 31 March-1 April 2006.

4 See Navarro in this IDS Bulletin on the topic of 'misrecognition'.

5 See Riddell (1987) for a discussion of these debates.

6 Jean-Philippe Therien (2002) argues that the right tends to see aid as charity, but I would suggest that this relates to personal individual giving from a rich person to a poor person through the voluntary sector, typified by the child-sponsorship NGOs. In terms of public sector recognise that there is both a positive and shadow side of the aid relationship. To make a charitable gift represents affection, caring and responsibility but it is also about power, violence and aggression (Amariglio 2002). Nevertheless, although the giving and receiving of gifts expresses hatred and resentment as well as love and friendship, I agree with the argument that a gift can be sufficiently noble to overcome its shadow side (Caillé 2000).

Finally, the gift privileges relationship building. I have argued elsewhere that the quality of relationships within and between organisations in the web of aid is crucial for long-term effectiveness. What are now considered old-fashioned reasons for aid - for example the idea of 'solidarity' that used to underpin Swedish aid - recognised the importance of relationships and did not perceive them as an unfortunate 'transaction cost'.

I therefore conclude that the power of the gift can enable international aid to support the achievement of social justice and poverty reduction provided that those in the world of aid recognise their practices for what they are and thus by making it visible learn to better manage the shadow side and promote the positive aspects of a socially embedded relationship, which is what a gift expresses.

transfers, the case for aid is either economic (future markets) or political (the furtherance of a country's self interest).

7 See my analysis in Eyben with León (2005).

8 Poverty Reduction Strategy paper. Bolivia was one of the first highly indebted countries to prepare a PRSP that was endorsed by the World Bank and the IMF in July 2001.

9 Personal communication from Nancy Okail (2006).

10 One observer interviewed for the independent evaluation remarked that 'DFID has had more influence per dollar than any other donor in Bolivia' (Flint et al. 2005: 2)

11 A phrase coined by John Gaventa, with which I became familiar later.

12 The UK Secretary of State for International Development (1997-2003)

13 See also Wilson and Eyben (2006).

14 Personal communication from one of those present at a meeting in La Paz in late 2003.

15 Personal communication from another informant (2005). 


\section{References}

Appadurai, A. (1985) 'Gratitude as a Social Mode in South India', Ethos 13.3: 236-45

Amariglio, Jack (2002) 'Give the Ghost a Chance', in Mark Osteen (ed.) The Question of the Gift: Essays Across Disciplines, London: Routledge

Bourdieu, P. (1998) Practical Reason, On the Theory of Action, London: Polity Press

Bourdieu, P. (1990) The Logic of Practice, London: Polity Press

Caillé, A. (2000) Anthropologie du Don, Le Tiers Paradigme, Paris: Descléw de Brouwer

Callari, A. (2002) 'The Ghost of the Gift: The Unlikelihood of Economics', in Mark Osteen (ed.), The Question of the Gift: Essays Across Disciplines, London: Routledge

Carrier, J. (1996) 'Exchange', in A. Barnard and J. Spencer (eds), Encyclopaedia of Social and Cultural Anthropology, London: Routledge: 218-21

Chambers, R. (1997) Whose Reality Counts?, London: Intermediate Technology Development Group (ITDG)

Crabtree, J. (2005) Patterns of Protest: Politics and Social Movements in Bolivia, London: Latin America Bureau

Crewe, E. and Harrison, E. (1998) Whose Development? An Ethnography of Aid, London: Zed Books

Eyben, R. (2005) 'Donors' Learning Difficulties: Results, Relationships and Responsibilities', IDS Bulletin 36.3: 98-107

Eyben, R. (2004) 'Who Owns a Poverty Reduction Strategy? A Case of Power, Instruments and Relationships in Bolivia', in R. Hinton and L. Groves (eds), Inclusive Aid, London: Earthscan

Eyben, R. (2003) The Rise of Rights, IDS Policy Briefing 17, Brighton: IDS

Eyben, R. with León, R. (2005) 'Whose Aid? The Case of the Bolivian Elections Project', in D. Lewis and D. Mosse (eds), The Aid Effect: Giving and Governing in International Development, London: Pluto Press

Flint, M., Rance, S. and Richardson, L. (2005) Evaluation of DFID Country Programmes: Country Study of Bolivia 2000-2004, Evaluation Report EV 656, London: Department for International Development (DFID)

Hattori, T. (2001) 'Reconceptualizing Foreign Aid', Review of International Political Economy 8.4 Oxford, Routledge: 633-60

Helmsing, A.H.J., Aguilar, J., Toranzo, C., Rojas, G., Guevara, J. Paul and Romero, C. (2003) Evaluation del PSAC: Apoyo a la Decentralización' Minsterio de Hacienda, Unidad de Decentralización Fiscal, La Paz: Bolivia

Mirowski, P. (2001) 'Refusing the Gift', in Stephen Cullenberg, Jack Amariglio and David Ruccio (eds), Postmodernism, Economics and Knowledge, London: Routledge

Nickson, R.A. (2002) Bolivia: A Country Case Study, International Development Department, University of Birmingham. Funded and Commissioned by OECD DAC Task Force on Donor Practices: Paris

OECD (2005) Paris Declaration on Aid Effectiveness, High Level Forum, 28 February-2 March, Paris: DAC of the OECD

Osteen, M. (2002) The Question of the Gift: Essays Across Disciplines, London: Routledge

Piron, L.H. (2002) The Right to Development: A Review of the Current State of the Debate, see Annex $V$ on Donor Governments and International Organisations (2002), prepared for the UK Department for International Development, www.odi.org.uk/pppg/publications/papers_reports/ dfid/issues/rightsO1/index.html (accessed 21 July 2006)

Pritchett, L. and Woolcock, M. (2004) 'Solutions When the Solution is the Problem: Arraying the Disarray in Development', World Development 32.2: 191-212

Riddell, R. (1987) Foreign Aid Reconsidered, Baltimore: Johns Hopkins University Press and London: James Currey

Sampson, S. (2002) 'What is a Donor?', European Association of Social Anthropologists Newsletter 34

Stirrat, R.L. and Henkel, H. (1997) 'The Development Gift: The Problem of Reciprocity in the NGO World', Annals AAPS 554: 66-80

Strathern, M. (1994) The Gender of the Gift, Berkeley: University of California Press

Therien, Jean-Philippe (2002) 'Debating Foreign Aid: Right Versus Left', Third World Quarterly 23.3: 449-66

Wilson, F. and Eyben, R. (2006) 'Supporting Rights and Nurturing Networks: The Case of the UK Department for International Development in Peru' in R. Eyben (ed.), Relationships for Aid, London: Earthscan: 115-32

World Bank (2000) Bolivia: From Patronage to a Professional State, Institutional and Governance Reform Report, Washington DC: World Bank 